Quaternary Science Reviews 2020, Volume 232

\title{
Early Pleistocene conifer macrofossils from Happisburgh, Norfolk, UK, and their environmental implications for early hominin occupation.
}

\author{
Aljos Farjon ${ }^{1}$, David J. Horne ${ }^{2}$, Simon A. Parfitt ${ }^{3,}{ }^{4}$, Philip I. Buckland ${ }^{5}$, Mark D. Lewis ${ }^{3 *}$ \\ ${ }^{1}$ Herbarium, Royal Botanic Gardens, Kew, Richmond, Surrey TW9 3AE, UK. \\ ${ }^{2}$ School of Geography, Queen Mary University of London, Mile End Road, London E1 4NS, UK. \\ ${ }^{3}$ Department of Earth Sciences, Natural History Museum, Cromwell Rd., London SW7 5BD, UK. \\ ${ }^{4}$ Institute of Archaeology, University College London, 31-34 Gordon Square, London WC1H OPY, UK. \\ ${ }^{5}$ Environmental Archaeology Lab., Department of Historical, Philosophical and Religious Studies, Umeå \\ University, SE-901 87 Umeå, Sweden. \\ * Corresponding author: mark.lewis@nhm.ac.uk
}

Keywords: Pleistocene, Palaeoenvironment, Mutual Climatic Range, Conifers, Europe, Hominin.

\begin{abstract}
Continuing coastal erosion in the vicinity of Happisburgh in north Norfolk has revealed archaeological sites documenting early human presence during at least two episodes in the Early and Early Middle Pleistocene. At Happisburgh 3, the oldest archaeological site in northern Europe (approximately 900,000 years old) finds include at least 80 flint artefacts and human footprints associated with abundant, well-preserved organic remains. The deposits consist of gravels and estuarine sands and silts contained within a complex of channels, which accumulated in the estuary of a large river, probably the ancestral River Thames. The environmental remains reflect a slow-flowing tidal river, at the limit of tidal influence, and a grassland valley bordered
\end{abstract}


by conifer-dominated woodland. Analyses of the pollen, wood, cones and leaves have identified a diversity of coniferous taxa, with some unexpected central and southern European elements (Pinus mugo ssp. mugo, Pinus mugo ssp. rotundata and Juniperus thurifera) indicating a type of coniferous woodland no longer present in Europe today. Here we present the conifer finds and their environmental implications. A new multi-proxy consensus palaeoclimate reconstruction, using conifer and beetle mutual climatic ranges, confirms and refines previous indications of a more continental climate than today, with significantly colder winters. These results provide a new perspective for understanding the climate and environment encountered by Early Pleistocene hominins at the northernmost limit of their range.

\section{Introduction}

Over recent years, there has been heightened interest in understanding and interpreting the challenges faced by Lower Palaeolithic humans as they dispersed into mid-latitude regions of the northern hemisphere, particularly with regard to the adverse climatic conditions they would have encountered (Hosfield, 2015; 2017) and the associated range of behavioural, cultural and physiological adaptations required to survive in these habitats (Ashton and Lewis, 2012; Hosfield and Cole, 2018; MacDonald, 2018). Evidence of hominin occupations in Eurasia during the Early Pleistocene is limited, with most well-dated sites (Michel et al., 2017; Figure 1) located at more southerly latitudes (e.g. Dmanisi, Orce, Atapuerca), and sites with a full complement of biological proxies are rare anywhere. Continuity of human occupation in Eurasia in the late Early Pleistocene, especially with respect to glacial-interglacial climate variability, is still hotly debated (MacDonald et al., 2012). The evidence from Happisburgh 3 (HSB3) that the earliest humans in Britain inhabited a landscape of conifer-dominated forests and colder winters (Parfitt et al., 2010) is controversial because it challenges a widely-held view that humans - part of the southern European biota - ventured into northern latitudes when their preferred habitat 
expanded in response to climatic warming (Parfitt et al., 2005; Roebroeks, 2006; Leroy et al., 2011).

In addition, there has recently been increased discussion concerning site distribution differences in north-west Europe before and after the 'Cromerian Complex' (Cohen et al., 2012). The earlier sites are located in coastal and coastal-plain environments with flake and core technology (Hosfield and Cole, 2018) but after about 500,000 years ago there is increasing evidence of hominins with Acheulean technology at more inland continental sites in these northern higher latitudes (Cohen et al., 2012), often also during the later post-temperate stages of interglacial periods (Candy et al., 2015; Whittaker and Parfitt, 2017).

One such Early Pleistocene coastal site is HSB3, currently the oldest archaeological site in northern Europe, dating to approximately 900,000 years ago (Parfitt et al., 2010). Previous environmental interpretation, based primarily on beetle Mutual Climatic Range (MCR) temperature estimates and palaeobotany, especially the purported presence of Pinus sylvestris L., suggested a modern climate analogue for HSB3 could be found in southern Scandinavia near the boundary between the temperate and boreal vegetation zones. Palynology also showed a conifer dominated signal consistent with this interpretation. This reconstruction is highly significant when considered alongside the evidence of early human presence at Happisburgh, raising questions about whether their expansion into northern latitudes was facilitated by physical adaptation or winter survival strategies (such as seasonal migration or innovations in hunting, clothing, use of shelters or control of fire) (Parfitt et al., 2010; Hosfield, 2015). However, analysis of new conifer macrofossil material, along with re-identification of existing conifer remains, shows the presence of taxa previously unknown from the British Pleistocene which currently have distributions in central Europe and Spain/north Africa. Here we develop a new 
MCR method using the conifer taxa and use an expanded calibration data set for the beetle MCR estimates. This approach refines climate reconstruction at the site using newly-developed climate envelopes. In this paper, we describe the new taxa and the climatic and ecological implications, reassessing the environmental context with respect to human occupation.

\section{Site context}

Happisburgh $3\left(52.826783^{\circ} \mathrm{N}, 1.532234^{\circ} \mathrm{E}\right)$ is located on the North Sea coast of Norfolk, UK, a coastline which has seen rapid erosion at many locations over the recent past. At Happisburgh this has uncovered several Lower Palaeolithic sites (Parfitt et al., 2010), sealed beneath glacial sediments (West, 1980) deposited by the earliest incursion of ice into lowland Britain during Marine Isotope Stage (MIS) 12. The interglacial sediments at HSB3 consist of a complex of fluvial gravels interdigitating with estuarine sands and silts, infilling channels which accumulated in the upper part of the estuary of a large river. This system had an extensive inland catchment area and drained into the North Sea; far-travelled clasts link this system to the ancestral River Thames (Parfitt et al., 2010). Finds from these sediments include about 80 flint artefacts; additionally, in 2013 human footprints were found within the estuarine silts (Ashton et al., 2014). Rich environmental evidence (large mammals, small vertebrates, insects, barnacles, molluscs, foraminifera, seeds, pollen and wood) associated with the artefacts reflects a slowflowing river, with tidal influence, bordered by grasslands and extensive conifer-dominated woodland at the end of an Early Pleistocene Interglacial period. A palaeomagnetic signal from the fine-grained channel deposits records reversed polarity which, along with biostratigraphy and lithostratigraphy, indicates that human occupation occurred towards the end of the Matuyama Chron between 0.99 and 0.78 million years ago (Parfitt et al., 2010) probably during MIS 25 or MIS 21. 


\section{Methods and provenance of the studied material}

The conifer remains from HSB3 include cones, many fragmentary pieces, branchlets and a needle recovered from archaeological trenches primarily during 2008 (Supplementary Data [SD] tables 1 and 2). These provide evidence of six taxa all relating directly to the published stratigraphic scheme (Parfitt et al., 2010). Cones 1 to 11 were found in association with lithic artefacts and recovered through coarse-mesh sieving $(1 \mathrm{~cm})$ of bulk sediments of Bed E (Trenches D and E). Organic remains from these units include substantial quantities of conifer wood (Gale in Parfitt et al., 2010) and conifer dominated pollen assemblages as well as beetles used for the MCR reconstruction (Parfitt et al., 2010). The branchlets and a conifer needle were recovered from a column of samples through Bed $\mathrm{F}$ which were wet sieved at the Natural History Museum (NHM), London.

Nine further cones (12 to 20) were recovered during careful searching of foreshore exposures at HSB3 over a period of several years. They are all in situ and from the interdigitating gravels, sands and silts that can be linked to the stratigraphic sequence established for the archaeological trenches. Cone 12 was found in the footprint horizon in 2013. Particular care was taken to assign these finds to stratigraphic context by sediment types, total-station surveying and in some cases palynological analysis of sediments associated with the cones. All finds were identified using the comparative collections at the Herbarium, Royal Botanic Gardens, Kew, London and at the NHM, London. Identifications were performed following the morphological descriptions and terminology used by Farjon (2005, 2017).

\section{Taxonomy}

\section{Pinus mugo Turra}

All cones from the 2008 excavations were previously identified as either Pinus sylvestris L., Pinus sp. or Picea (Parfitt et al., 2010). Cones 1 to 11 are all in the family Pinaceae but are now 
assigned to Pinus mugo ssp. mugo, as also is cone 12 from the footprint horizon. Fragments found with some of these cones $(1,6,7,9,11$; SD table 1$)$ are also likely to belong to $P$. mugo but are too broken or eroded to make certain identifications. Additionally, other partial and/or damaged cones were found but were missing the diagnostic upper parts of the seed scales. They are not included here. All belong to Pinaceae but are too fragmentary for certain identification. For certain identification, the upper part (apophysis, i.e. the part of the seed scale that expands in the first year of two years of growth) has to be well preserved. This is the part of the scale that is visible in a closed cone (see Figure 1a). In P. sylvestris this is only very slightly raised and clearly transversely keeled; in $P$. mugo at least those scale parts exposed to sunlight when growing (upper side of cone) are thickened with often a sunken centre and the transverse keel is absent or only obscurely visible. Although variable, in $P$. mugo ssp. rotundata this feature is even more pronounced than in $P$. mugo ssp. mugo, making the cones asymmetrical in appearance (see Figure1b).

Pinus mugo Turra ssp. rotundata (Link) Janch. \& Neumayer

Cones 13 and 14, found together, and cones 15 and 16 also found together, belong to a subspecies of Pinus mugo, P. mugo ssp. rotundata, a taxon found both as a low shrub and upright tree, the former more frequent in wet moorland and boggy habitats. The cones of this subspecies and of Pinus uncinata are similar and have strongly raised apophyses on the sunward side of the cone (when attached). P. uncinata cones are slightly larger than those found at HSB3 and this species has a more south-westerly distribution in Europe, $P$. mugo ssp. rotundata is more central-European, but there is much overlap of ranges. Identification to ssp. rotundata seems the more plausible considering current distribution and habitat preference (bog margins). 


\section{Juniperus thurifera $\mathrm{L}$.}

Numerous (pen)ultimate branchlets of Juniperus and a few fragments of pollen cones of the same were found throughout Bed F (see SD table 2). The branchlets are identified as the southwest European/north African species $J$. thurifera. This is usually a tree but sometimes a large shrub; often preferring basic substrates, it is now most widespread in Spain and Morocco, with more localized occurrences in France and Algeria (Farjon and Filer, 2013). No other scale-leaved junipers in Europe agree with the nearly eglandular (i.e. lacking a resin gland visible on the exterior leaf cuticle) leaves seen in the material. Some of the J. thurifera specimens were sent for DNA analysis but were found to have none remaining.

\section{Abies alba Mill.}

A fragmented needle of a conifer was recovered from Trench I, sample 350. The base and apex are damaged or missing, but otherwise it is well preserved and stomata are clearly visible (Figure 1e). The most likely species is Abies alba, agreeing in leaf width and narrow margins along the stomatal bands, now with a distribution in Central Europe.

Picea abies (L.) H. Karst.

Cones 17, 18 and 19 can be assigned to the genus Picea. Cone 17, found with cones 15 and 16 (P. mugo ssp. rotundata), seems most likely to be Picea abies (less so P. obovata-type) as the other two extant European species can be ruled out on morphological grounds. Cones 18 and 19 are badly preserved and fragmentary, but can be assigned to the genus Picea. Other British and Irish Pleistocene cones have been assigned to P. obovata (Chambers, 1994) or to intermediate types (hybrid forms: $P$. xfennica). Cone 17 agrees with the latter in size, but the distal scale margins, although not all intact, are not rounded and smooth. It is probably of a northern type, as today seen in Scandinavia and the Baltic area. 
Pinus cf. peuce Griseb.

A cone (20) was recovered most likely belonging to Pinus subgenus Strobus section

Quinquefolia. The scales appear to be strongly reflexed but the collector observed that this was less so when first found and that its deformation occurred mainly with drying. The specimen is not well preserved. The European species to which to assign it would therefore be Pinus peuce, although this is done here tentatively and due to this uncertain identification we have excluded it from the climate analysis.

It is notable that wood of Pinus, Picea and other, but unknown, conifers was recorded by Gale in Beds E and F (Parfitt et al., 2010), as well as Juniperus in Bed D. Additionally, the pollen signal of these beds is dominated by conifers. Pinus mugo ssp. mugo, P. mugo ssp. rotundata, Pinus peuce and Juniperus thurifera are previously unknown from the British Pleistocene; the recovered macrofossil of Abies alba is the earliest record from the British Pleistocene.

\section{Distribution and Ecology}

With the presence of Pinus, Picea and Abies and likely of Tsuga, the latter known from pollen in previous reports (West, 1980; Parfitt et al., 2010), the total of genera in Pinaceae found at HSB3 is four. There is further evidence of Juniperus (wood and now branchlets and pollen cones) and Larix (pollen and possible wood), Taxus, and Sequoia (pollen) (Parfitt et al., 2010). The conifer taxa are summarised in table 1. Of Pinus there are two species, one with two subspecies. Boreal conifer forests often include no more than one or two species; however, Picea abies occurs in these forests as well as further south. Abies alba and Pinus mugo s.l. are now largely central European species, although P. mugo ssp. mugo (a shrubby taxon found today in montane habitats) has a distribution from the Pyrenees to the Carpathians, including the more southerly 
Rhodope Mountains and the Apennines (Farjon, 2005, 2017). Pinus peuce occurs in the Balkan Peninsula. All species in Pinaceae are low montane to montane in central Europe. Juniperus thurifera in Europe is most widespread in Spain, with outliers in the French Pyrenees and Alps, and rare occurrences in adjacent Italy and in Corsica. Its elevation range in Europe is 200-1800m and in France and Spain it is typical of open woodland with Quercus, characterized climatically by cold winters and warm and dry summers, although in Cantabria this juniper occurs in nearoceanic conditions.

This assemblage of conifers found at HSB3 suggests a coniferous woodland of greater diversity than is found anywhere in central or northern Europe at the present time. The cones in many cases appear damaged by transport, most likely in a river (Parfitt et al., 2010) but possibly by tidal movement. The juniper branchlets are extremely well preserved and must have floated before deposition. With the exception of Juniperus thurifera, which at least in Spain is mostly associated with limestone, and to some extent Taxus baccata, the conifers of HSB3 occur on acidic to neutral substrates. It is possible that Juniperus and Taxus occurred on nearby chalk outcrops. Evidence of river transport may indicate that the Pinaceae also extended well into the higher catchment and so may also have occurred at some distance from the juniper woodland. This still leaves a relatively diverse conifer forest, more diverse but not very dissimilar to conifer forests now present in central Europe. The species Pinus mugo could have grown as an understorey shrub below Picea abies; it is now a montane low canopy conifer, but there are parallels with related conifers in East Asia. Figure 2 shows the present-day distributions of Pinus mugo ssp. mugo, P. mugo ssp. rotundata and Juniperus thurifera. 


\section{Palaeoclimate reconstruction}

A previous quantitative palaeoclimatic reconstruction for HSB3 used the beetle MCR method to determine ranges of mean monthly (July and January) air temperatures (Parfitt et al. 2010). The results (table 2) indicated summer temperatures similar to those of today in the same area, but winter temperatures significantly colder by at least $4{ }^{\circ} \mathrm{C}$ (mean temperature of coldest month). However, results based on a single proxy (in this case the MCR of beetles) should not be accepted uncritically, irrespective of how mathematically robust the underlying model is. Mutual Climatic Range methods use present-day and historical climatic temperature ranges of living species and museum specimens to determine the temperature ranges within which the species in a fossil assemblage could have co-existed in the past. Typically such methods reconstruct $\mathrm{T}_{\mathrm{MIN}}$ (the mean air temperature of the coldest month, i.e. January in the northern hemisphere), $\mathrm{T}_{\mathrm{MAX}}$ (the mean air temperature of the warmest month, i.e. July in the northern hemisphere), and $\mathrm{T}_{\text {RANGE }}$ (the difference between $\mathrm{T}_{\mathrm{MAX}}$ and $\mathrm{T}_{\mathrm{MIN}}$; a measure of seasonality). Any such method will likely produce a plausible result, but in order to demonstrate that it is trustworthy there is a need for testing and verification against other data. Such testing, if carried out at all, has often been unsatisfactory. Birks et al. (2010: 78) outlined how strong spatial autocorrelation between the geographical distributions of taxa and climatic variables renders testing with independent datasets of the same organism group problematic, and concluded that "Comparison of reconstructions with palaeoclimate records developed from other, independent climate proxies therefore seems the only way of evaluating MCR-based inferences...”. Our Multi-Proxy Consensus (MPC) approach tests the results of independent proxy methods against each other, based on the premise that if two or more such methods are "telling the truth" about a given site/time interval then they must produce consistent, overlapping (but not necessarily identical) results; then, if they pass the test, they can be used to determine refined "mutual mutual" ranges (Holmes et al., 2010; Langford et al., 2014a, 2014b, 2017). The new conifer finds offered an 
excellent opportunity to carry out such a test and apply an MPC approach to HSB3, albeit one that required the development of a new MCR method for conifer macrofossils. Distributional data for five conifer taxa found at HSB3 were extracted from the Conifer Database, the source of An Atlas of the World's Conifers (Farjon and Filer, 2013). The data presented therein discounted planted conifers from gardens, parks etc. and therefore approximate natural distributions of the taxa. This resulted in an initial dataset comprising Abies alba (127 records), Juniperus thurifera (63 records), Picea abies (208 records), Pinus mugo ssp. mugo (112 records) and Pinus mugo ssp. rotundata (45 records). Pinus cf. peuce was not included because of the tentative nature of its identification.

These data were mapped using DIVA-GIS version 7.5.0 (Hijmans et al., 2001) and the distribution of each species was compared with mean January and July temperatures from the WorldClim (version 1.3) interpolated climate dataset (Hijmans et al., 2005) with a resolution of 2.5 minutes of arc, also mapped in DIVA-GIS. Temperature data were extracted for each conifer record and used to plot their distributions in "climate space", each of the plots showing a cluster and a few outliers. Small errors in geographical position (particularly in areas of high topographical relief) may result in erroneous temperature determinations, so the shapefiles produced in DIVA-GIS were used to make Keyhole Markup Language (KML) files that could be viewed in Google Earth Pro to facilitate inspection and discussion of the geographical positions of the outliers in the climate space plots. Four outlying records (one each of $J$. thurifera, $P$. abies, A. alba and P. mugo ssp. rotundata) were thus determined to be improbable due to evident locational errors, and were removed from the dataset; seven other cases were considered acceptable and were retained. Envelopes were drawn around the adjusted plots for each taxon (as a convex hull linking the outermost points and enclosing all the rest). The 
resulting five envelopes were plotted together and their mutual overlap used to determine $\mathrm{T}_{\mathrm{MAX}}$, $\mathrm{T}_{\mathrm{MIN}}$ and $\mathrm{T}_{\mathrm{RANGE}}$ (to the nearest $1{ }^{\circ} \mathrm{C}$ ) (Figure 3).

The temperature ranges reconstructed by the conifer MCR method (table 2) are somewhat wider than, but enclose (and are therefore consistent with), the published beetle MCR reconstruction of Parfitt et al. (2010). This in itself is a satisfying outcome that inspires confidence in both proxy methods, but the past decade has seen substantial further development in the beetle MCR method and it was considered advisable to review and, if necessary, revise the results published by Parfitt et al. (2010).

The original beetle based reconstruction of Parfitt et al. (2010) used the thermal envelopes of 34 taxa to derive the area of mutual climatic range in climate space. The present reconstruction uses 36 species, adding three new thermal envelopes (Bembidion obliquum (Sturm), Bembidion guttula (F.), and Acidota crenata (F.)) but dropping the uncertain identification of Bembidion cf. velox (L.) from the original reconstruction (SD table 3). The addition of three taxa results from the use of an expanded calibration dataset in the BugsCEP software (Buckland and Buckland 2006), derived from envelopes originally created by Perry (1986) and imported into the Bugs database (see Buckland 2007 for a more complete developmental history).

The addition of three new taxa to the climate reconstruction, while reinforcing the existing results, does not in itself refine the reconstructed temperature values. In fact, a jackknife analysis indicates that the new reconstruction is unusually stable, and that the MCR values would only be affected by the removal of two individual taxa (SD table 3). Removal of Bembidion clarkii (Dawson) has no effect on summer temperatures, but leads to a lowering of the winter reconstruction to -5 to $-1{ }^{\circ} \mathrm{C}$ and an increase in $\mathrm{T}_{\text {RANGE }}$ to 18 to $21{ }^{\circ} \mathrm{C}$. This marsh/woodland 
ground beetle has a well-defined, oceanic (low $\mathrm{T}_{\mathrm{RANGE}} \mathrm{span}$ ) thermal envelope, and would have been at the limit of its tolerance for continentality at Happisburgh. The removal of the rove beetle Arpedium quadrum (Grav.), now extinct in the British Isles (Buckland and Buckland 2018), leads to a reconstruction equivalent to Parfitt et al. (2010). The poorly defined thermal envelope of this species, included in both reconstructions, defines the upper limit of $\mathrm{T}_{\mathrm{MAX}}$ in the MCR. It is possible that differences in the resolution of this envelope between the two calibration sets are the reason for the differences in reconstructed temperatures. MCR analysis may sometimes only produce a temperature reconstruction for part of a sample fauna. In the case of this updated analysis of the HSB3 beetles, $100 \%$ of the fauna would have been able to survive any climatic variation within the range of reconstructed temperatures, and thus the MCR results strongly support the taphonomic integrity of the sample.

To summarise, the revised beetle MCR application produces narrower ranges than the original one, the upper limits of $\mathrm{T}_{\mathrm{MIN}}$ and $\mathrm{T}_{\mathrm{MAX}}$ both being reduced by one degree; the two results nevertheless remain consistent and overlapping (table 2). Both the original and revised beetle MCR results overlap and are consistent with the conifer MCR result. The two proxy methods therefore pass the MPC test and can be used to determine refined mutual ranges within which the conifer and the beetle taxa could have co-existed: $\mathrm{T}_{\mathrm{MIN}}-3$ to $-1{ }^{\circ} \mathrm{C}, \mathrm{T}_{\mathrm{MAX}}+16$ to $+17{ }^{\circ} \mathrm{C}, \mathrm{T}_{\mathrm{RANGE}}$ 18 to $19^{\circ} \mathrm{C}$. Note that these are identical with the revised beetle MCR envelope which falls within the conifer MCR envelope; the former result is validated and strengthened by the latter. The MPC result confirms that HSB3 climate was of a more continental character than the present oceanic or maritime climate, with substantially greater seasonal variation; summers were similar to those of today (or no more than one degree cooler) but winters were significantly colder (by at least $5{ }^{\circ} \mathrm{C}$ ). A European modern analogue for such a climatic regime can be found in Denmark and southern Sweden today. 


\section{Discussion and conclusion}

Most Early and early Middle Pleistocene archaeological sites in Britain (e.g. Boxgrove, Waverley Wood, Happisburgh 1) are associated with conifer-dominated woodlands (Ashton and Lewis, 2012; Candy et al., 2015). The characteristics of environments at these sites, particularly in terms of productivity and potential resources for humans, as well as the climatic implications, are important. These conifer-dominated woodlands may also represent interstadial periods and not necessarily just the later part of interglacials. The assumption that we have a close modern analogue with the current southern Scandinavian boreal belt, a biotope extending across much of northern Eurasia, needs to be tested. HSB3 is the most informative site, due to multiple environmental and climatic proxies, for investigating the structure and composition of plant and animal communities of an Early Pleistocene conifer-dominated woodland.

The British Early Pleistocene plant macrofossil record is poor, but at HSB3 there is now macrofossil evidence of a diverse conifer flora with an unusual combination of taxa including Pinus mugo ssp. mugo, P. mugo ssp. rotundata, Juniperus thurifera and Pinus cf. peuce. This non-analogue assemblage also includes taxa more commonly found in the British Pleistocene, such as Picea abies and Abies alba, the former already reported from HSB3 (Parfitt et al., 2010) and the latter known in later Pleistocene stages but unknown in Early Pleistocene Britain before this record. The presence of macrofossils of these conifer taxa, with the addition of significant beetle data, leads to a number of interesting observations in terms of environment and ecology at HSB3, as well as in the more wide-ranging implications of climate and hominin incursions this far north during the Early Pleistocene, and the associated potential behavioural adaptations.

Although the conifer assemblage presented here is unique in the British Pleistocene record, with some taxa unrecorded before now, the presence of taxa exotic to the present British flora in the 
Cromer Forest-bed Formation (CF-bF) during the Early and early Middle Pleistocene is not an isolated phenomenon and has been recognised for some time. West (1980) records 32 'exotic' taxa from pre-Anglian glaciation coastal sites in East Anglia, including the conifers Picea abies, Picea omorika and Tsuga, although the latter two only from pollen. However, two types of Tsuga pollen are identified by him, T. canadensis-type and $T$. diversifolia-type and, although not abundant, are present in sufficient enough numbers at many of the studied sites, particularly Happisburgh, for West to consider it very likely that the genus was present in East Anglia during the Pastonian. Duigan (1963) also records Tsuga in diagram BB from Happisburgh. Wilson (1973) cites a figure of $8 \%$ exotic taxa from Cromer Forest Bed locations, including a leaf of Picea omorika from Pastonian III/IV levels at Beeston.

If we include pollen and wood evidence (Parfitt et al., 2010) there are ten conifer taxa in the HSB3 assemblage (listed in table 1), indicating a diverse conifer flora. Some of the taxa, such as Tsuga, are remnants of an even more diverse conifer flora that existed in the late Pliocene, which included Sciadopitys and Taxodium (Andrew and West, 1977). A diminishing number of these Neogene 'relict' taxa persisted into the early stages of the Pleistocene in what became a gradually decreasing conifer diversity, most probably partly due to the increasing severity of climatic changes associated with the Pleistocene. The concomitant reduced proximity of refugial areas would also have played a part. By the time of the HSB3 interglacial (Parfitt et al., 2010) evidence for most of these taxa had all but disappeared, with only Tsuga pollen present in low frequencies at a number of East Anglian sites (West, 1980), but enough not to be considered reworked. The presence of Tsuga together with Pinus mugo and Juniperus thurifera in the Happisburgh assemblage can be seen as part of this overall pattern. 
Existing conifer material in the collections of the Earth Science Department at the NHM, London, was re-examined by one of us (AF). Most of this material, belonging to a number of collections, was found at pre-glacial localities along the coast over the past 200 years, some by Eleanor and Clement Reid (Reid, 1882, 1899). In a number of cases, fossils that had previously been identified as Pinus sylvestris, Pinus sp., or simply 'cone' have now been assigned to Pinus mugo, or in other instances to Picea abies (SD table 4).

The pollen, wood and macrofossil evidence presented above suggest that there is a coherent conifer assemblage at HSB3 in these levels, representative of a contemporary flora growing in the vicinity of the site. Strong support for this interpretation is provided by the beetle evidence, notably the occurrence at HSB3 of conifer-dependent beetle species including Hylurgops palliates (Gyll.), Tomicus (synonym Blastophagus) piniperda (L.), Polygraphus poligraphus (L.) and Rhyncolus elongatus (Gyll.). These beetles primarily require dead wood of Picea, Abies, Larix and Pinus (Coope in Parfitt et al., 2010). Along with the presence of identified wood, this evidence of association would suggest these beetle taxa, and their tree hosts, must have been local or at least regional. Pollen taphonomy problems of shallow marine and estuarine sediments highlighted by Gibbard (1988) should be taken into consideration, but the other lines of evidence suggest a locally deposited assemblage. For example, remains of rooted trees are also recorded from HSB3 and a wood sample taken from one of these in May 2016 was identified as belonging to Pinaceae (Rowena Gale, pers. comm.).

Having established the taphonomic integrity of the assemblage, this has allowed us to reconstruct the palaeoclimate of human occupation using the MCR method with conifers and beetles, reaching the MPC values presented in table 2. We consider the MPC result to be highly significant, not least because it confirms and inspires confidence in the results of the two 
independent proxies; we hesitate to claim that it means the results are accurate, because that can never be known for certain, but we would argue that having passed the test they can at least be considered "more accurate" than results based on a single, inadequately tested proxy method. Compared to the previously published reconstruction based on a single proxy (Parfitt et al., 2010), the new results confirm summer temperatures similar to those of today, but (most significantly) emphasize that winters were markedly colder by at least $5{ }^{\circ} \mathrm{C}$. This difference in mean January temperature is equivalent to the present day latitudinal difference between southern England and Mediterranean northern Spain.

It is interesting to compare the HSB3 results with palaeotemperature reconstructions obtained with the herpetile Mutual Ecogeographic Range (MER) method by Blain et al. (2018) for the MIS 21 Gran Dolina (TD6) human occupation site in northern Spain. Their results (Blain et al., 2018: Table 2) for mean summer temperature vary from $+18.5( \pm 2.1){ }^{\circ} \mathrm{C}$ to $+20.3( \pm 1.2){ }^{\circ} \mathrm{C}$, from which they calculate differences from present-day temperature of +0.1 and $+1.9{ }^{\circ} \mathrm{C}$ respectively (i.e. very similar or, at most, less than $2{ }^{\circ} \mathrm{C}$ warmer). These, however are mean values, calculated from reconstructed ranges that are not shown by Blain et al. (2018) but were originally provided (as minima and maxima), in addition to means and standard deviations, by Blain et al. (2009). The overall ranges for the combined TD6 levels are +15.0 to $+22.5^{\circ} \mathrm{C}$ (summer) and -1.0 to $+7.5^{\circ} \mathrm{C}$ (winter). Compared with the present-day mean summer $(+18.4$ $\left.{ }^{\circ} \mathrm{C}\right)$ and winter $\left(+2.6^{\circ} \mathrm{C}\right)$ temperatures this indicates that MIS 21 summer palaeotemperatures could have been similar to that of today or as much as $4.1{ }^{\circ} \mathrm{C}$ warmer or $3.4{ }^{\circ} \mathrm{C}$ cooler, and mean winter temperatures could have been similar to that of today or as much as $4.9{ }^{\circ} \mathrm{C}$ warmer or 3.6 ${ }^{\circ} \mathrm{C}$ cooler. In summary, Blain et al. (2018) interpret their results as indicating a temperate Mediterranean palaeoclimate with both summers and winters similar to or somewhat warmer than today; our interpretation of their results, on the other hand, would allow the additional 
possibility that summers and /or winters may have been significantly cooler. This is not to say that Blain et al. (2018) are wrong, however; a recent publication by Altolaguirre et al. (2018) has used an MPC approach (although they do not name it as such) to compare results from Blain et al. (2009) with new ones based on pollen and leaf assemblages using the Coexistence Approach (Mosbrugger and Utescher, 1997; Utescher et al., 2014; Alcalde-Olivares et al., 2004). They find that the two proxy methods give consistent results, thus validating them, but stop short of using them to determine narrower "mutual mutual" ranges in the way that we have done for HSB3.

It is beyond the scope of the present paper to assess whether the apparent precision (calculation of means to one decimal place) of the MER method used by Blain et al. (2018) is indicative of greater accuracy, but in MCR methods (including our own new conifer MCR method) we work to a precision of one whole degree (no decimal places) and consider it questionable whether the mean of the upper and lower values of a range has a greater probability (than any other value within that range) of being correct (Buckland, 2007; Horne et al., 2012a). Comparability of sites is also problematic due to chronological uncertainties; since HSB3 is assigned to either MIS 25 or MIS 21 and most likely represents the second half of an interglacial (Parfitt et al., 2010) it can only tentatively be regarded as approximately equivalent to Gran Dolina TD6, which is assigned to MIS 21 and held to include the interglacial optimum (Blain et al., 2018).

The above issues notwithstanding, it is noteworthy that, according to the mean values given by Blain et al. (2018), the maximum latitudinal palaeotemperature gradient apparent between HSB3 and Gran Dolina TD6 would be from +16.0 to $+20.3{ }^{\circ} \mathrm{C}$ to $\left(=4.3{ }^{\circ} \mathrm{C}\right)$ in summer and from -3.0 to $+3.8{ }^{\circ} \mathrm{C}\left(=6.8{ }^{\circ} \mathrm{C}\right)$ in winter, very different from the present-day gradient of only $1{ }^{\circ} \mathrm{C}(+17$ to $+18)$ in summer and a negative gradient of $1.4{ }^{\circ} \mathrm{C}(+4$ to +2.6$)$ in winter. Today the Gran Dolina site has summers only slightly warmer, and winters cooler, than Happisburgh, largely because 
although the Spanish site is at lower latitude it is also at higher altitude. This emphasizes not only the apparent difference in palaeoclimate of the two sites but also the difficulty of making meaningful comparisons.

Our confirmation of a continental climate with high seasonality at HSB3 contradicts the conclusion of Kahlke et al. (2011), based on western Palaearctic habitat diversity inferred from large mammal communities, that seasonality was low in NW Europe when humans first ventured there. It also challenges the view that these early humans dispersed northwards as climatic warming extended their southern European habitats to higher latitudes (Parfitt et al., 2005; Roebroeks, 2006; Leroy et al., 2011). We must therefore address the question of why NW European climate in MIS 25 or MIS 21 should have had greater seasonal extremes than it does today. The oceanic or maritime climate of NW Europe today is relatively mild and humid in comparison with the colder and drier continental interior, but this is more a consequence of the Atlantic Meridional Overturning Circulation (AMOC; involving heat exchange between warm surface waters and cold air masses circulating eastwards, so that winters are significantly milder than those in Canada at the same latitudes) than of simple proximity to the sea, although the coastal zone may also experience a more equable climatic regime due the ameliorating effect of an adjacent large body of water. A strong AMOC enhances the northward transport of heat by the surface North Atlantic Current (NAC), while during times of reduced AMOC (e.g. in glacials) the NAC moves to more southerly position, sometimes as far as the northern Iberian margin, resulting in reduced sea surface temperatures in higher North Atlantic latitudes (MartinGarcia, 2019). The Mid-Pleistocene Transition (c. 1.25 to c. $0.7 \mathrm{Ma}$ ) is associated with a substantial change in AMOC (Lawrence et al., 2010). Candy and McClymont (2013) observed that the MIS 19 to MIS 13 interglacials appeared to be characterised by equatorward shift of the Polar Front which delineates the northern extent of the NAC, as compared to MIS 11 to MIS 1 
interglacials. Our palaeoclimate reconstruction for MIS 21 at HSB3 indicates a more continental climate, in spite of being near the coast, implying that the AMOC was either reduced or did not reach as far north as today, a scenario supported by Atlantic deep ocean sediment core evidence for a weaker AMOC prior to MIS 16, especially during glacials, with the NAC in a southerly position (Martin-Garcia et al., 2018).

The range of challenges, limiting factors and the potential physiological and behavioural adaptations required for hominins to survive at northerly latitudes have already been discussed in detail (Ashton and Lewis, 2012; Hosfield, 2015; MacDonald, 2018), the debate focusing on winter cold and availability of resources, principally food. MacDonald (2018) concluded that without controlled use of fire (ruled out due to lack of evidence) two strategies were plausible, one physiological (winter fur, i.e. more body hair, and subcutaneous fat) and the other technological (clothing, e.g. animal skins, to conserve biological heat production) but for which (as far as the HSB humans are concerned) there is also a lack of evidence. Although food availability may not have been the most critical limiting factor, while summers may have been warm, by comparison with their southern European refugia (Stewart and Stringer, 2012) winters must have presented the HSB3 hominins with serious survival challenges, such as sub-zero temperatures, a reduced growing season, fewer edible plants, sparser mammalian prey and shorter daylight hours (Ashton and Lewis, 2012). Hosfield (2015) argued for the effectiveness of a winter residence strategy (rather than annual migration) that could have included the use of fire, clothing, the autumn/winter storage of surplus food resources and the exploitation of resources offered by woodland-fringed rivers and coastal estuaries. Conifer forests alone have a low productivity (Clarke, 1976) but the evidence from HSB3 is of a mixed woodland environment with a mosaic of varied habitats, rich in resources. These include animals and plants associated with the bordering grasslands, and the location of HSB3 at a tidally-influenced 
large river estuary in a near-coastal setting may be an additional factor favouring hominin survival. Coastal zones in this context also include the bordering coastal plains, with their associated freshwater environments. Estuaries and alluvial plains are the most ecologically productive environments for both plant and animal resources, followed closely by the adjacent moist forests and grasslands (Clarke, 1976). Seasonal availability of plant foods, such as berries, nuts and fungi at these ecotones would have provided additional resources. Hunting opportunities in the grassland environments would also have existed and although human-plantanimal relationships are undoubtedly complex, they are adaptively flexible with patterns changing over time. The advantage of the coastal location of HSB3, in terms of potential resource availability, is further enhanced by the year-round presence of rich marine resources such as shellfish and seaweeds which, in combination with reduced seasonality of such resources in northern (when compared to more southerly) latitudes, are particularly relevant for hominin survival, especially in the winter months.

The research challenge is to find evidence for possible coping strategies, which may have included seasonal migration, improved technology, control of fire, use of shelters and/or clothing, and increased dependence on meat, more efficient hunting and scavenging and more effective social cooperation. In this context, our improved palaeoclimate reconstruction establishes a more robust baseline for continued debate about survival strategies at the earliest human occupation site in NW Europe.

\section{Acknowledgements.}

Many individuals and organisations have assisted with the fieldwork that has led to the retrieval of the Happisburgh specimens. In particular we thank Nick Ashton and Simon Lewis for organising fieldwork. We would like to thank Robert Adams of the Gruver Laboratory in Texas, 
USA, for DNA analysis of the juniper branchlets; Peter Hoare and John Whittaker for processing sediment samples; Mike Field and Rowena Gale for macrofossil identifications; Harry Taylor at the NHM for photography and Consuelo Sendino for help with Photoshop; Malcolm Penn for help with ArcGIS (Maps created using ArcGIS® software by Esri. Copyright @ Esri); Peta Hayes for access to the Forest Bed cones in the NHM collections; The NHM and Royal Botanic Gardens, Kew are thanked for giving access to their herbarium collections. Tireless searching by Darren Nicholas, Joanne Leonard and Nigel Larkin has resulted in many important discoveries from the Happisburgh foreshore. Much of the fieldwork and analyses were funded by the Leverhulme Trust as part of the Ancient Human Occupation of Britain project and fieldwork also by the British Museum. Subsequently, the work has been largely funded by the Calleva Foundation's Pathways to Ancient Britain Project. Survey work of the beach was funded by Historic England. The support of the Calleva Foundation to ML and SP is gratefully acknowledged. We would like to express our gratitude to Hugues-Alexandre Blain and an anonymous reviewer for constructive criticism and suggestions which have helped us to improve our paper.

\section{The authors declare no competing interests.}

\section{Appendix A. Supplementary data}

Supplementary data related to this article can be found after the figures, at the end of this repository version of the paper.

\section{Data availability.}

All fossil insect data used in this paper are available for download in the open access database BugsCEP (www.bugscep.com) and online through the Strategic Environmental Archaeology

Database (www.sead.se). The conifer data used in this paper for the palaeoclimate reconstruction are available at: https://herbaria.plants.ox.ac.uk/bol/conifers 


\section{References}

Alcalde-Olivares, C., García-Antón, M., Gómez-Manzaneque, F., Morla, C., 2004.

Palaeoenvironmental interpretation of the Neogene locality Caranceja (Reocín, Cantabria, N Spain) from comparative studies of wood, charcoal and pollen. Review of Palaeobotany and Palynology 132, 133-157.

Altolaguirre, Y., Postigo-Mijarra, J.M., Barrón, E., Carrion, J.S., Leroy, S.A.G., Bruch, A.A. 2019. An environmental scenario for the earliest hominins in the Iberian Peninsula: Early Pleistocene palaeovegetation and palaeoclimate. Review of Palaeobotany and Palynology 260, $51-64$

Andrews, R., West, R.G., 1977. Pollen spectra from Pliocene Crag at Orford, Suffolk. New Phytologist 78, 709-714.

Ashton, N., Lewis, S.G., 2012. The environmental contexts of early human occupation of northwest Europe: The British Lower Palaeolithic record. Quaternary International 271, 50-64.

Ashton, N.M., Lewis, S.G., De Groote, I. Duffy, S. Bates, M., Bates, R., Hoare, P.G., Lewis, M., Parfitt, S.A., Peglar, S. Williams, C. and Stringer, C.B., 2014. Hominin footprints from Early Pleistocene deposits at Happisburgh, UK. PlosOne:

http://dx.plos.org/10.1371/journal.pone.0088329

Birks, H.J.B., Heiri, O., Seppä, H., Bjune, A.E. 2010. Strengths and weaknesses of quantitative climate reconstructions based on Late-Quaternary biological proxies. The Open Ecology Journal $3,68-110$.

Blain, H.-A., Bailon, S., Cuenca-Besco, G., Arsuaga, J.L., Bermúdez de Castro, J.M., Carbonell, E. 2009. Long-term climate record inferred from early-middle Pleistocene amphibian and squamate reptile assemblages at the Gran Dolina Cave, Atapuerca, Spain. Journal of Human Evolution 56, 55-65.

Blain, H.-A., Cruz Silva, J.A., Jiménez-Arenas, J.M., Margari, V., Roucoux K. 2018. Towards a Middle Pleistocene terrestrial climate reconstruction based on herpetofaunal assemblages from the Iberian Peninsula: state of the art and perspectives. Quaternary Science Reviews 191, 167188.

Buckland, P.I., 2007. The development and implementation of software for palaeoenvironmental and palaeoclimatological research: the Bugs Coleopteran Ecology Package (BugsCEP) (PhD thesis). Archaeology and Environment, 23. Umeå.

http://urn.kb.se/resolve?urn=urn:nbn:se:umu:diva-1105

Buckland, P.I., Buckland, P.C., 2006. BugsCEP Coleopteran Ecology Package. IGBP PAGES/World Data Center for Paleoclimatology Data Contribution Series \# 2006-116. NOAA/NCDC Paleoclimatology Program, Boulder CO, USA.

http://www.ncdc.noaa.gov/paleo/insect.html or http://www.bugscep.com 
Buckland, P. I., Buckland, P. C., 2018. Species found as fossils in Quaternary sediments. In: Duff, A.G. (Ed.), Checklist of Beetles of the British Isles: with a chapter on fossil beetles (3rd edition ). Iver: Pemberley Books, pp. 171-174.

Candy, I., McClymont, E. L. 2013. Interglacial intensity in the North Atlantic over the last 800 000 years: investigating the complexity of the mid-Brunhes Event. Journal of Quaternary Science 28, 343-348.

Candy, I., Schreve D., White, T. S., 2015. MIS 13-12 in Britain and the North Atlantic: understanding the palaeoclimatic context of the earliest Acheulean. Journal of Quaternary Science 30(7), 593-609.

Chambers, F.M., 1994. Spruce, resembling Picea obovata Ledebour, from Late-Pleistocene deposits in north Wales. Quaternary Newsletter 72, 10-17.

Clarke, D., 1976, Mesolithic Europe; the economic basis. In: G. de G. Sieveking, I. H. Longworth, K. E. Wilson (Eds.), Problems in Economic and Social Archaeology. London: Duckworth, pp. 449-481.

Cohen, K.M., MacDonald, K., Joordens, J.C.A., Roebroeks, W., Gibbard, P.L., 2012. The earliest occupation of north-west Europe: a coastal perspective. Quaternary International 271, $70-83$.

Duigan, S. L., 1963. Pollen analyses of the Cromer Forest Bed Series in East Anglia. Philosophical Transactions of the Royal Society B 246, 149-202.

Farjon, A., 2005. Pines. Drawings and descriptions of the genus Pinus. Brill, Leiden and Boston (2nd Edition).

Farjon, A., 2017. A Handbook of the World's Conifers. Vol. 2. Brill, Leiden and Boston (2nd Edition).

Farjon, A. and Filer, D., 2013. An Atlas of the World's Conifers. An analysis of their distribution, biogeography, diversity and conservation status. Brill, Leiden and Boston.

Gibbard, P.L. 1988. Palynological problems and the vegetational sequence of the Pliocene preglacial Pleistocene of East Anglia. In: Gibbard, P.L. and Zalasiewicz, J.A. (Eds.) Pliocene Middle Pleistocene of East Anglia. Field Guide. Quaternary Research Association: Cambridge, pp. 42-49.

Hijmans, R.J., Guarino, L., Cruz, M., Rojas, E., 2001. Computer tools for spatial analysis of plant genetic resources data: 1. DIVA-GIS. Plant Genetic Resources Newsletter 127, 15-19.

Hijmans, R.J., Cameron, S.E., Parra, J.L., Jones, P.G., Jarvis, A., 2005. Very high resolution interpolated climate surfaces for global land areas. International Journal of Climatology 25, 1965-1978.

Holmes, J. A., Atkinson, T., Darbyshire, D. P. F., Horne, D. J., Joordens, J., Roberts, M. B., Sinka, K. J., Whittaker, J. E., 2010. Middle Pleistocene climate and hydrological environment at 
the Boxgrove hominin site (West Sussex, UK) from ostracod records. Quaternary Science Reviews 29, 1515-1527.

Horne, D.J., Curry, B.B., Mesquita-Joanes, F., 2012. Mutual climatic range methods for Quaternary ostracods. In: Horne, D.J., Holmes, J.A., Rodriguez-Lazaro, J., Viehberg, F.A. (Eds) Ostracoda as Proxies for Quaternary Climate Change. Developments in Quaternary Science 17, 65-84. Elsevier

Hosfield, R., 2015. Walking in a Winter Wonderland? Strategies for Early and Middle Pleistocene Survival in Midlatitude Europe. Current Anthropology 57 (5), 653-682.

Hosfield, R. 2017. A Reply to Gilligan. Current Anthropology 58 (4), 536.

Hosfield, R., Cole, J., 2018. Early hominins in north-west Europe: A punctuated long chronology? Quaternary Science Reviews 190, 148-160.

Kahlke, R.-D., Garcia, N., Kostopoulos, D.S., Lacombat, F., Lister, A.M., Mazza, P.A., Spassov, N., Titov, V.V. 2011. Western Palaearctic palaeoenvironmental conditions during the Early and early Middle Pleistocene inferred from large mammal communities, and implications for hominin dispersal in Europe. Quaternary Science Reviews 30, 1368-1395.

Langford, H.E., Boreham, S., Briant, R.M., Coope, G.R., Horne, D.J., Schreve, D.C., Whittaker, J.E., Whitehouse, N.J., 2014a. Middle to Late Pleistocene palaeoecological reconstructions and palaeotemperature estimates for cold/cool stage deposits at Whittlesey, eastern England. Quaternary International 341, 6-26.

Langford, H.E., Boreham, S., Coope, G.R., Fletcher,W., Horne, D.J., Keen, D.H., Mighall T., Penkman, K.E.H., Schreve, D.C. and Whittaker, J.E., 2014b. Palaeoecology of a late MIS 7 interglacial deposit from eastern England. Quaternary International 341, 27-45.

Langford, H.E., Boreham, S., Briant, R.M., Coope, G.R., Horne, D.J., Penkman, K.E.H., Schreve, D.C., Whitehouse, N.J. and Whittaker, J.E., 2017. Evidence for the early onset of the Ipswichian thermal optimum: palaeoecology of Last Interglacial deposits at Whittlesey, eastern England. Journal of the Geological Society 174, 988-1003.

Lawrence, K.T., Sosdian, S., White, H.E, Rosenthal, Y. 2010. North Atlantic climate evolution through the Plio-Pleistocene climate transitions. Earth and Planetary Science Letters 300, 329342.

Leroy, S.A.G., Arpe, K., Mikolajewicz, U. 2011. Vegetation context and climatic limits of the Early Pleistocene hominin dispersal in Europe. Quaternary Science Reviews 30, 1448-1463.

MacDonald, K., Martinón-Torres, M., Dennell, R.W., Bermúdez de Castro, J-M., 2012. Discontinuity in the record for hominin occupation in south-western Europe: Implications for occupation of the middle latitudes of Europe. Quaternary International 271, 84-97.

MacDonald K., 2018. Fire-free hominin strategies for coping with cool winter temperatures in north-western Europe from before 800,000 to circa 400,000 years ago. Palaeoanthropology 2018, 7-26. 
Martin-Garcia, G.M. 2019. Oceanic impact on European climate changes during the Quaternary. Geosciences 9,119, 1-21.

Martin-Garcia, G.M., Sierro, F.J., Flores, J.A., Abrantes, F. 2018. Change in the North Atlantic circulation associated with the mid-Pleistocene transition. Climate Past 14, 1639-1651.

Michel, V., Shen, C-C., Woodhead, J., Hu, H-M., Wu, C-C., Moullé. P-E., Khatib, S., Cauche, D., Marie-Hélène Moncel, M-H., Valensi, P., Chou, Y-M., Gallet, S., Echassoux, A., Orange, F., de Lumley, H., 2017. New dating evidence of the early presence of hominins in southern Europe. Nature Scientific Reports 7, 10074.

Mosbrugger, V., Utescher, T., 1997. The coexistence approach — a method for quantitative reconstructions of tertiary terrestrial palaeoclimate data using plant fossils. Palaeogeography, Palaeoclimatology, Palaeoecology 134, 61-66.

Parfitt, S.A., Barendregt, R.W., Breda, M., Candy, I., Collins, M.J., Cooper, G.R., Durbidge, P., Fields, M.H., Lee, J.R., Lister, A.M., Mutch, R., Penkman, K.E.H., Preece, R.C., Rose, J., Stringer, C.B., Symmons, R., Whittaker, J.E., Wymer, J.J., Stuart, A.J. 2005. The earliest record of human activity in northern Europe. Nature 438, 1008-1012.

Parfitt S., Ashton N., Lewis, S., Abel R., Coope G.R., Field M., Gale R., Hoare P., Larkin N., Lewis M., Karloukovski V., Maher B., Peglar S., Preece R., Whittaker J., Stringer C., 2010. Early Pleistocene human occupation at the edge of the boreal zone in northwest Europe. Nature 466, 229-233.

Perry, D.W., 1986. The analysis of sub-fossil insect assemblages: a numerical approach (Doctoral dissertation, The University of Birmingham).

Reid, C., 1882. The geology of the country around Cromer. Memoirs of the Geological Survey of England and Wales, sheet memoirs $68 \mathrm{E}$.

Reid, C., 1899. The Origin of the British Flora. Dulau, London. 234 pp.

Roebroeks, W. 2006. The human colonisation of Europe: where are we? Journal of Quaternary Science 21, 425-435.

Stewart, J.R., Stringer, C.B., 2012. Human evolution out of Africa: the role of refugia and climate change. Science 335, 1317-21.

Utescher, T., Bruch, A.A., Erdei, B., François, L., Jacques, F.M.B., Kern, A.K., Liu, Y.S.(.C.)., Mosbrugger, V., Spicer, R.A., 2014. The coexistence approach - Theoretical background and practical considerations of using plant fossils for climate quantification. Palaeogeography, Palaeoclimatology, Palaeoecology 410, 58-73.

West RG., 1980. The Pre-glacial Pleistocene of the Norfolk and Suffolk Coasts. Cambridge University Press. 
Whittaker J.E., Parfitt S.A., 2017.The palaeoenvironment of the important Middle Pleistocene hominin site at Boxgrove (West Sussex, UK) as delineated by the foraminifera and ostracods. In: Williams, M., Hill, T., Boomer, I. and Wilkinson, I. P. (Eds.) The Archaeological and Forensic Applications of Microfossils: A Deeper Understanding of Human History. The Micropalaeontological Society, Special Publications. Geological Society, London. pp. 9-34.

Wilson D.G., 1973. Notable plant records from the Cromer Forest Bed Series. New Phytologist $72,1207-1234$. 


\begin{tabular}{lccc} 
Taxon & $\begin{array}{c}\text { Macrofossils } \\
\text { (this paper) }\end{array}$ & $\begin{array}{c}\text { Wood (Gale in } \\
\text { Parfitt et al., 2010) }\end{array}$ & $\begin{array}{c}\text { Pollen (Peglar \& Lewis } \\
\text { in Parfitt et al., 2010) }\end{array}$ \\
\hline Pinus mugo ssp. mugo & $\checkmark$ & - & - \\
P. mugo ssp. rotundata & $\checkmark$ & - & - \\
Pinus peuce & $\checkmark$ & - & - \\
Pinus & - & - & - \\
Picea abies & $\checkmark$ & - & $\checkmark$ \\
Picea & - & $\checkmark$ & - \\
Picea/Larix & - & - & - \\
Juniperus thurifera & $\checkmark$ & $\checkmark$ & $\checkmark$ \\
Juniperus & - & - & $\checkmark$ \\
Cupressaceae & - & - & - \\
Sequoia & - & - & $\checkmark$ \\
Abies alba & $\checkmark$ & - & $\checkmark$ \\
Abies & - & - & $\checkmark$ \\
Tsuga & - & - & $\checkmark$ \\
Larix & - & - & \\
Taxus & - & & \\
\hline
\end{tabular}

Table 1. Conifer remains from Early Pleistocene channel deposits at Happisburgh 3.

$\begin{array}{cccc}\begin{array}{c}\text { Mean January } \\ \text { air temperature } \\ \left({ }^{\circ} \mathrm{C}\right)\end{array} & \begin{array}{c}\mathrm{T}_{\text {Mean July }} \\ \text { air temperature } \\ \left({ }^{\circ} \mathrm{C}\right)\end{array} & \begin{array}{c}\mathrm{T}_{\text {MANGE }} \\ \left({ }^{\circ} \mathrm{C}\right)\end{array} & \begin{array}{c}\text { Number } \\ \text { of } \\ \text { taxa }\end{array} \\ +4 & +17 & 13 & \\ -3 \text { to } 0 & +16 \text { to }+18 & \begin{array}{c}\text { not } \\ \text { published }\end{array} & 34 \\ -3 \text { to }-1 & +16 \text { to }+17 & 18 \text { to } 19 & 36 \\ -4 \text { to }+1 & +15 \text { to }+19 & 17 \text { to } 21 & 5 \\ -3 \text { to }-1 & +16 \text { to }+17 & 18 \text { to } 19 & \end{array}$

Table 2. Palaeotemperature reconstruction results for Happisburgh 3. 


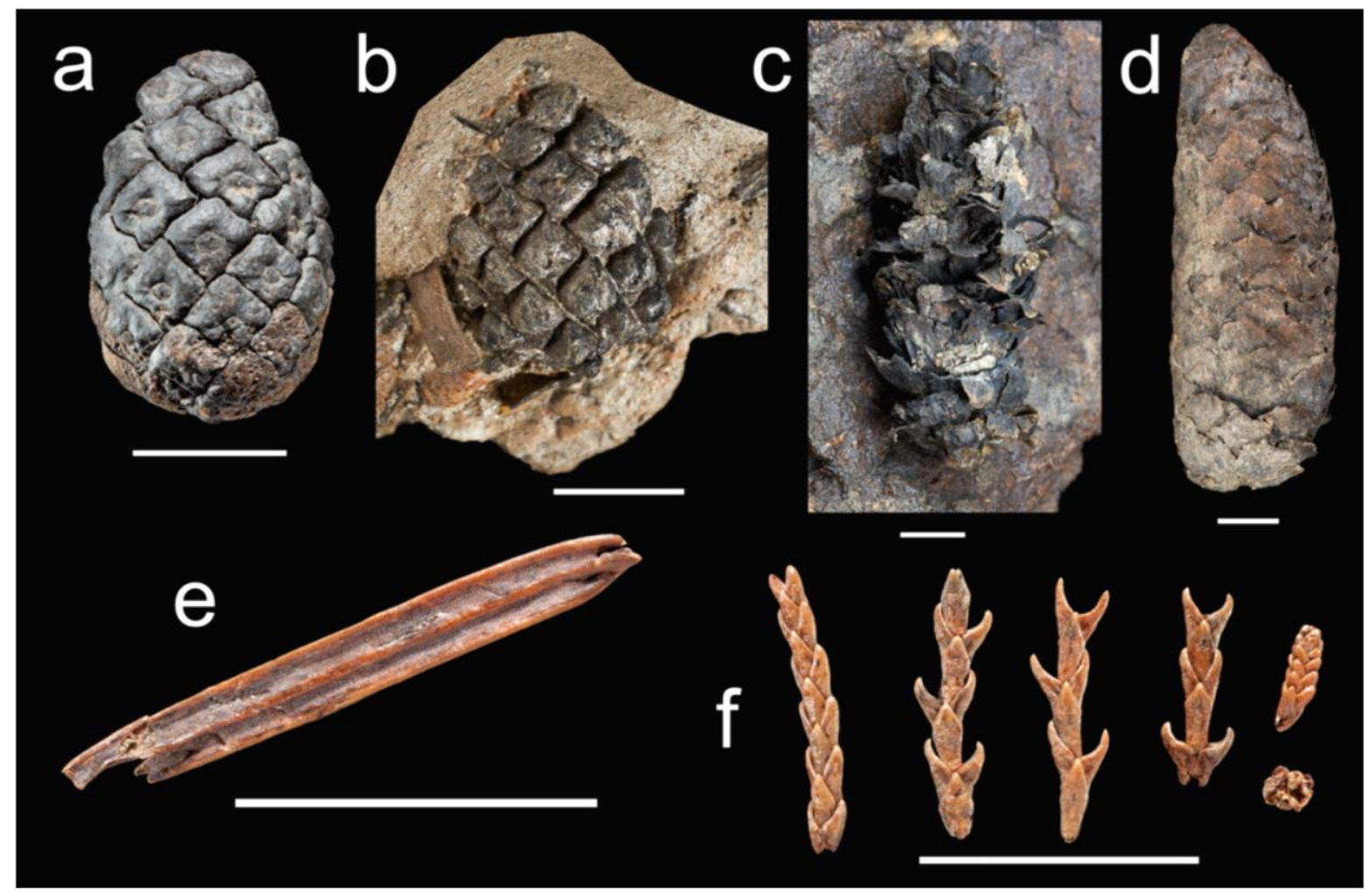

Figure 1. Conifer macrofossils from Happisburgh 3. Cones of: a) Pinus mugo ssp. mugo [NHMUK V 68778]; b) P. mugo ssp. rotundata [NHMUK V 68783]; c) Pinus peuce (Pinus subgenus Strobus section Quinquefolia) [NHMUK V 68787] ; d) Picea abies [NHMUK V 68784]; e) needle of Abies alba [NHMUK V 68797]; f) branchlets and pollen cones of Juniperus thurifera [NHMUK V 68788b]. (Scale bars $=10 \mathrm{~mm}$ ). 

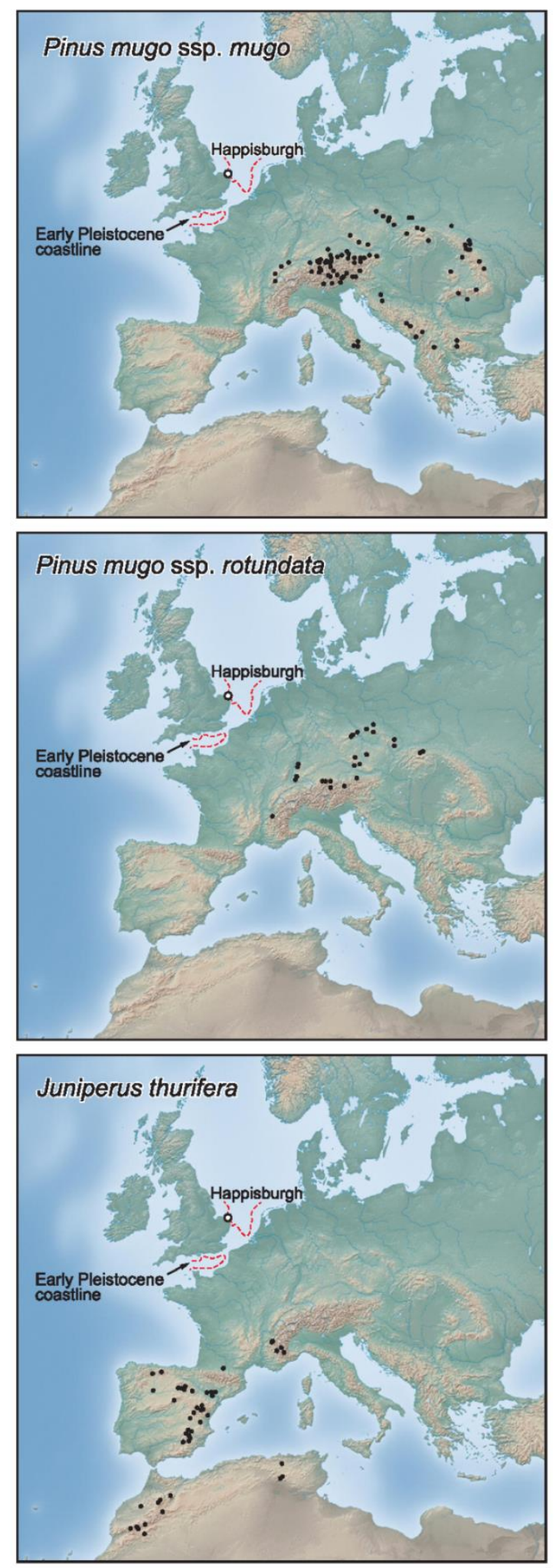

Figure 2. Modern distributions of Pinus mugo ssp. mugo, P. mugo ssp. rotundata and Juniperus thurifera based on specimens in the Conifer Database used for An Atlas of the World's Conifers (Farjon and Filer, 2013). The British Early Pleistocene coastline is shown, Britain being a peninsula of the European mainland at the time. 


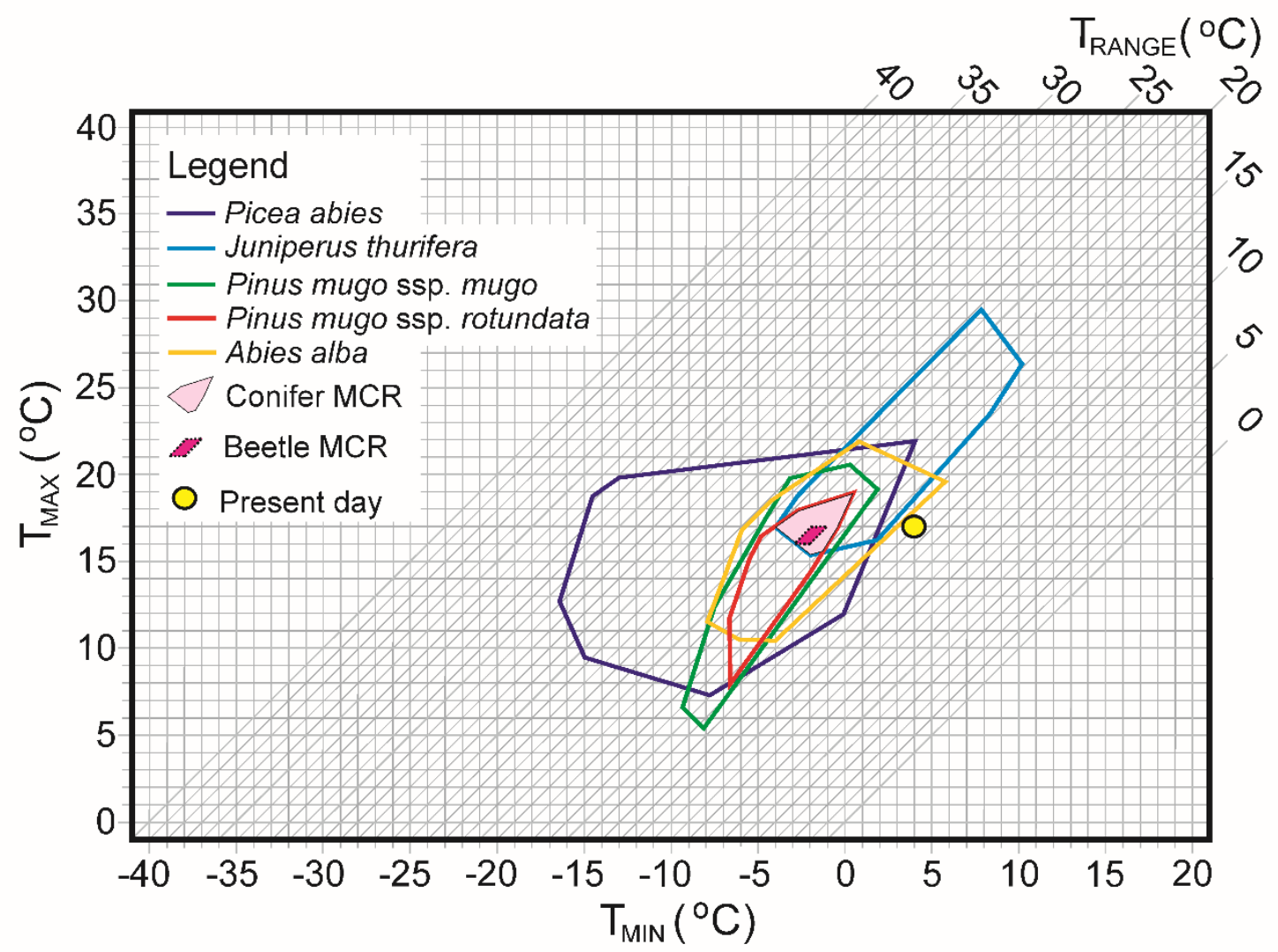

Figure 3. Plot of "climate space" temperature envelopes for five conifer taxa from Happisburgh 3 and the resulting mutual climatic range envelope, compared with the beetle MCR method result and present-day values. 


\begin{tabular}{|c|c|c|c|c|c|c|}
\hline \multirow[t]{2}{*}{ Text specimen no. } & \multirow[t]{2}{*}{ NHM number } & \multicolumn{2}{|r|}{ Locality } & \multirow[t]{2}{*}{ Bed } & \multirow[t]{2}{*}{ Type of remains } & \multirow[t]{2}{*}{ Taxon } \\
\hline & & Trench & Foreshore exposure (Long./Lat.) & & & \\
\hline 1 & NHMUK V 68770 & E & & $\mathrm{E}$ & Cone & P. mиgo ssp. mugo \\
\hline 2 & NHMUK V 68771 & E & & $\mathrm{E}$ & Cone & P. mugo ssp. mugo \\
\hline 3 & NHMUK V 68772 & E & & E & Cone & P. mugo ssp. mugo \\
\hline 4 & NHMUK V 68773 & $\mathrm{D}$ & & $\mathrm{E}$ & Cone & P. mugo ssp. mugo \\
\hline 5 & NHMUK V 68774 & $\mathrm{D}$ & & $\mathrm{E}$ & Cone & P. mиgo ssp. mиgo \\
\hline 6 & NHMUK V 68775 & $\mathrm{D}$ & & $\mathrm{E}$ & Cone & P. mugo ssp. mugo \\
\hline 7 & NHMUK V 68776 & D & & E & Cone & P. mugo ssp. mugo \\
\hline 8 & NHMUK V 68777 & E/D baulk & & $\mathrm{E}$ & Cone & P. mugo ssp. mugo \\
\hline 9 & NHMUK V 68778 & $\mathrm{E}$ & & $\mathrm{E}$ & Cone & P. mugo ssp. mugo \\
\hline 10 & NHMUK V 68596 & $\mathrm{E}$ & & $\mathrm{E}$ & Cone & P. mиgo ssp. mиgo \\
\hline 11 & NHMUK V 68779 & E & & E & Cone & P. mugo ssp. mugo \\
\hline 12 & NHMUK V 68780 & & $52.825198,1.5350671$ & F ('j' of West, 1980) & Cone & P. mugo ssp. mugo \\
\hline 13 & NHMUK V 68781 (1) & & $52.826235,1.5334672$ & & Cone & P. mugo ssp. rotundata \\
\hline 14 & NHMUK V 68781 (2) & & $52.826235,1.5334672$ & & Cone & P. mugo ssp. rotundata \\
\hline 15 & NHMUK V 68782 & & $52.826461,1.5331332$ & & Cone & P. mugo ssp. rotundata \\
\hline 16 & NHMUK V 68783 & & $52.826461,1.5331332$ & & Cone & P. mugo ssp. rotundata \\
\hline 17 & NHMUK V 68784 & & $52.826461,1.5331332$ & & Cone & Picea abies \\
\hline 18 & NHMUK V 68785 & & $52.828128,1.5300769$ & & Cone & cf. Picea abies \\
\hline 19 & NHMUK V 68786 & & $52.828126,1.5300750$ & & Cone & cf. Picea abies \\
\hline 20 & NHMUK V 68787 & & $52.824660,1.5362352$ & & Cone & Pinus subgenus Strobus section \\
\hline
\end{tabular}

SD Table 1. Contextual information and taxonomic identifications of cones recovered from archaeological trenches and foreshore exposures at Happisburgh 3.

\begin{tabular}{|c|c|c|c|c|c|c|}
\hline Sample & NHM number & Trench & Depth & Bed & Type of remains & Taxon \\
\hline 345 & NHMUK V 68796 & I & 0 to $10 \mathrm{~cm}$ & $\mathrm{~F}$ & Branchlet & Juniperus thurifera \\
\hline 346 & & I & 0 to $-10 \mathrm{~cm}$ & $\mathrm{~F}$ & & No recognizable plant material \\
\hline 347 & & I & -10 to $-20 \mathrm{~cm}$ & $\mathrm{~F}$ & & No recognizable plant material \\
\hline 348 & & I & -20 to $-30 \mathrm{~cm}$ & $\mathrm{~F}$ & & No recognizable plant material \\
\hline 350 & NHMUK V 68797 & I & -40 to $-50 \mathrm{~cm}$ & $\mathrm{~F}$ & Needle & Abies \\
\hline $1 \mathrm{~B}$ & NHMUK V 68788a \& V 68788b & $\mathrm{J} / \mathrm{K}$ & 20 to $30 \mathrm{~cm}$ & $\mathrm{~F}$ & Branchlets $(\mathrm{n}=\sim 55)$ & Juniperus thurifera \\
\hline $2 \mathrm{~B}$ & NHMUK V68789 & $\mathrm{J} / \mathrm{K}$ & 10 to $20 \mathrm{~cm}$ & $\mathrm{~F}$ & Branchlets $(\mathrm{n}=\sim 5)$ & Juniperus thurifera \\
\hline $3 \mathrm{~A}$ & NHMUK V 68790a \& V 68790b & $\mathrm{J} / \mathrm{K}$ & 0 to $10 \mathrm{~cm}$ & $\mathrm{~F}$ & Branchlets $(\mathrm{n}=\sim 50)$ & Juniperus thurifera \\
\hline $4 \mathrm{~B}$ & NHMUK V 68791 & $\mathrm{~J} / \mathrm{K}$ & 0 to $-10 \mathrm{~cm}$ & $\mathrm{~F}$ & Branchlets $(n=3)$ & Juniperus thurifera \\
\hline $5 \mathrm{~A}$ & NHMUK V 68792a \& V 68792b & $\mathrm{J} / \mathrm{K}$ & -10 to $-20 \mathrm{~cm}$ & $\mathrm{~F}$ & Branchlets $(\mathrm{n}=\sim 35)$ & Juniperus thurifera \\
\hline $6 \mathrm{~A}$ & NHMUK V 68793 & $\mathrm{~J} / \mathrm{K}$ & -20 to $-30 \mathrm{~cm}$ & $\mathrm{~F}$ & Branchlets $(n=10)$ & Juniperus thurifera \\
\hline $6 \mathrm{~B}$ & NHMUK V 68794a \& V 68794b & $\mathrm{J} / \mathrm{K}$ & -20 to $-30 \mathrm{~cm}$ & $\mathrm{~F}$ & Branchlets $(\mathrm{n}=\sim 30)$ & Juniperus thurifera \\
\hline $7 \mathrm{~B}$ & & $\mathrm{~J} / \mathrm{K}$ & -30 to $-40 \mathrm{~cm}$ & $\mathrm{~F}$ & Not found & Juniperus thurifera \\
\hline $8 \mathrm{C}$ & & $\mathrm{J} / \mathrm{K}$ & -40 to $-50 \mathrm{~cm}$ & $\mathrm{~F}$ & & No recognizable plant material \\
\hline $9 \mathrm{~B}$ & NHMUK V 68795 & $\mathrm{~J} / \mathrm{K}$ & -50 to $-60 \mathrm{~cm}$ & $\mathrm{~F}$ & Branchlets $(\mathrm{n}=2)$ & Juniperus thurifera \\
\hline
\end{tabular}

SD Table 2. Abies alba and Juniperus thurifera remains recovered from sieved samples. 


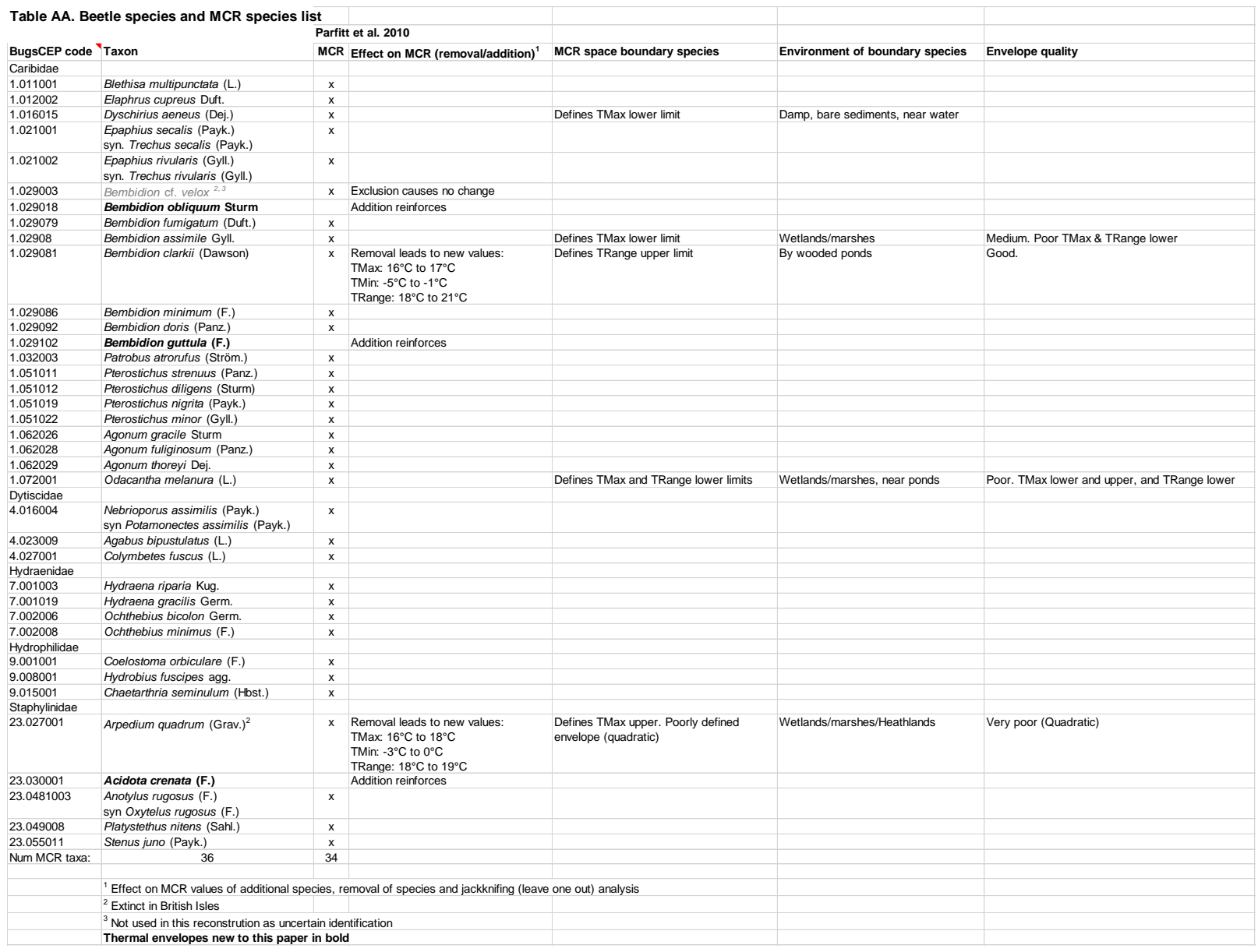

SD Table 3. Beetle species used in the MCR reconstruction for this paper, compared with Parfitt et al. 2010, and with notes on key species. See Parfitt et al. 2010 for the full species list and numbers of individuals. 


\begin{tabular}{|c|c|c|}
\hline Specimen Number & Taxon & Notes \\
\hline NHMUK V 17116 & Pinus sp. & Prestwich Collection (presented 1896) \\
\hline NHMUK V 17117 & Pinus mugo subsp. mugo & Prestwich Collection (presented 1896) \\
\hline NHMUK V 17118 & Picea abies & Prestwich Collection (presented 1896) \\
\hline NHMUK V 25434 & Pinus mugo & $\begin{array}{l}\text { Presented by E.M. Reid (June 1937). Figured: Reid, C. and Reid, E.M. 1908. On the pre-glacial } \\
\text { flora of Britain. Journal of the Linnean Society of London (Botany), 38, 206-227, pl. XV, fig. } 146\end{array}$ \\
\hline NHMUK V 37240 & Pinus mugo & C. Reid Collection (presented by M.E.J. Chandler, 1958). ?Cromer \\
\hline NHMUK V 37244 & Picea abies & C. Reid Collection (presented by M.E.J. Chandler, 1958) \\
\hline NHMUK 52836 & Picea abies & Cunnington Collection (registered 1876) \\
\hline NHMUK 17013 & Picea abies & Purchased from Rev. C. Green \\
\hline NHMUK V 68798 & Picea abies & Purchased from Rev. C. Green \\
\hline NHMUK V 68799 & Picea abies & Purchased from Rev. C. Green \\
\hline NHMUK V 68800 & Picea abies & Purchased from Rev. C. Green \\
\hline NHMUK V 68801 & Picea abies & Purchased from Rev. C. Green \\
\hline NHMUK V 68802 & Pinus sylvestris & Purchased from Rev. C. Green \\
\hline NHMUK V 68803 & Pinus sylvestris & Purchased from Rev. C. Green \\
\hline NHMUK V 68804 & Pinus cf. sylvestris & Purchased from Rev. C. Green \\
\hline NHMUK 16462 & Picea abies & Purchased from Rev. C. Green \\
\hline NHMUK 16465 & Pinus mugo & Purchased from Rev. C. Green \\
\hline NHMUK 17727 & Pinus sp. & Purchased from Rev. C. Green \\
\hline NHMUK 15189 & Picea abies & Purchased from Rev. C. Green \\
\hline NHMUK 15191 & Picea abies & Purchased from Rev. C. Green \\
\hline NHMUK 15192 & Picea? & Purchased from Rev. C. Green \\
\hline NHMUK 15193 & Pinus sylvestris & Purchased from Rev. C. Green \\
\hline NHMUK 15194 & Pinus mugo subsp. rotundata & Purchased from Rev. C. Green \\
\hline NHMUK V 2861 & Pinus sylvestris & H.S. Beckles collection (purchased 1891) \\
\hline NHMUK V 68805 & Pinus sylvestris & H.S. Beckles collection (purchased 1891) \\
\hline NHMUK V 68806 & Pinus sylvestris & H.S. Beckles collection (purchased 1891) \\
\hline NHMUK V 4428 & Picea abies & Norfolk coast \\
\hline NHMUK V 4432 & Pinaceae & Norfolk coast \\
\hline
\end{tabular}

SD Table 4: Conifer cones in the NHM (London) collections from pre-glacial deposits in Norfolk collected in the $19^{\text {th }}$ century. Determinations by Aljos Farjon. 